\title{
Assessing the Level Organizational Universities Agility; Case Study of Islamic Azad University in Mazandaran
}

\author{
Seyyed Abdollah Khavari \\ Ph.D Student. Department of Higher Educational Administration, Science and Research Branch, \\ Islamic Azad University, Tehran, Iran
}

Hamidreza Arasteh

Corresponding Author; Faculty of Management, Kharazmi University, Tehran, Iran

Parivash Jafari

Faculty of Department of Educational Administratuon, Science and Research Branch, Islamic Azad University, Tehran, Iran

\section{Doi:10.5901/mjss.2016.v7n3s2p112}

\begin{abstract}
This study aims to investigate the level of university organizational agility for branches of Islamic Azad University in Mazandaran Province. This study is a descriptive research during 2015. The statistical population included the faculty members of the branches of Islamic Azad University in Mazandaran Province. The statistical sample included 270 people using stratified random sampling and Cochran's formula. Data were collected through a researcher-made questionnaire consisting of 70 questions on seven factors based on the 2-point Likert scale. The questionnaire simultaneously measures the ideal status and current situation. Independent Samples Test was used to analyze data. According to the faculty members, the mean scores of organizational agility in universities was higher than the assumed mean 3 and there was a significant gap between current and ideal status in terms of achieving organizational agility.
\end{abstract}

Keywords: faculty members, organizational agility, organizational assessment, university branches, Islamic Azad University

\section{Introduction}

At the beginning of the 21st century, universities and higher education institutions experienced drastic changes. The developments such as increasing speed of technological changes, the changing nature of students' demand, changes in competition with other universities and research centers have increased the vulnerability of universities and higher education centers (Arasteh, 2010). Lack of attention to these challenges will affect the success of the educational organizations. It seems that the move towards establishing institutions having the speed and flexibility in responding to the needs of today's unpredictable environment, organizational agility is a suitable solution for the survival of universities. A model has been proposed for improving agility as an effective response to changing needs in a competitive market. Agility is a paradigm that leads to organizational capabilities against changes in customer needs and tracking the new requirements, achieving a strategic plan for competition skills, providing structural and procedural changes to respond to the needs, increasing the transparency of information and their application in the organization, optimizing the use of corporate resources, maximum use of technology. In an agile environment, an organization's ability to release the potential in people is the main factor for the success of the organizations. Sharifi and Zhang (1991) considered the function of agile organizations as increasing response rates, raising the level of staff competence, strength and flexibility of the organization against possible changes. Maskel (2001) considered four key elements for agile manufacturing, including consumer welfare, people and information, collaboration within and between organizations and appropriateness of a company for a change. Tsourveloudis et al. (2003) mentioned the main characteristics of the agile organization: flexibility and adaptability, accountability, integrity and low complexity, providing core competencies (capabilities and competencies for multilateral economic activities, development and promotion of business strategies which are difficult to implement, increasing knowledge and technology skills, a close relationship between customers and suppliers, introducing new products at high levels), high quality and improving products (goods and services, information and valueadded of contents, quality of each product, appropriate design for the first time and in a short period of development) 
culture of change (environmental support for testing, learning and innovation, positive attitude to changes, new ideas, people and technology, continuous improvement of employees' learning and training, change management, and organizational responsibility). According to Johnson (2004), Agility has three dimensions, including creation of services, the nature of services, and the provision of services. Agility capabilities include four dimensions: changes related to product functionality, suitability of change in operations, internal and external cooperation and educated manpower, learned and creative skills in organizations. Lin et al. (2006) mentioned the characteristics of agile organizations in the worldwide as follows: focus on the customer, learning organizations, knowledge management, and culture of changes. Booth et al. (2008) stated a concept of agile manufacturing and agile enablers, including human resources of agility, value management in agile organizations, concurrent engineering, technology and value management. Farzaneh et al. (2011) stated the basic indicators of organizational structure as follows: technology, teamwork, corporate and institutional integrity, authority, concentration, size of organization, time communication, recognition, qualifications, specialization, levels of the organization, complexity, focus of decision-making, and monitoring and evaluation. Raschkeh (2010) considered the organic type of organizational structure and organizational agility as intertwined. Plonka (1997) considered the main factors of creating agile organizations as knowledge-oriented manpower. In addition, he considered the role of leadership and management valuable for organizational agility through job rotation, selection of employees, creating incentives for employees. Breu et al. (2002) and Fathiyan et al. (2006) conducted empirical studies to analyze the role of information technology in creating organizational agility. Dove (1999) and Yusuf et al. (1999) considered organizational culture as one of the important underlying factors that have a direct impact on organizational agility. Bagherzadeh and Dibavar (2010) found that there is a significant relationship between organizational intelligence and organizational agility. However, the realities of the global environment and economic, political and social changes should drastically be changed in higher education. The realities, including the explosion of information and technology, new forms of competition, the end of the era of mass production, students' diverse needs and expectations, the rapid rate of changes, have created a competitive environment for higher education. The universities cannot prepare students for the new economy using old tactics and strategies. Thus, the higher education system and universities need some forms of agility. Sharp (2012) considered agility in universities as a strategic plan. He stated the components of agility as follows: strategic understanding, leadership, integrity, commitment and innovation, human resources and flexibility in resource. Different researches have been conducted to assess the level of agility. Zhank and Sharifi (2000) proposed a conceptual model and a methodology for measuring the agility in the industry with multiple support tools to help the manufacturing institutions with making a strategic decision to seek agile production. In this model, they considered agile stimuli that a company requires for doing business in new ways to maintain the competitive advantage. The stimuli can change from one company to another and from one location to another and thus the way of their effect can change on a company. As the changes and pressures are different for companies, different companies will have various degrees of agility. The degrees are defined as the level of agility required by the company, which is a direct function of various factors, including the volatility of the company's business environment, operating conditions and the level of complexity within the company. In fact, when the conditions are more varied and complex for doing businesses, organizations need to be more agile. Therefore, the business conditions indicators for a company include the perception of changes and a range of different factors for stimuli and agility, and comprehension of the complexity and internal conditions. The required agility level for a company shows the possibility of staying in business, maintaining a competitive advantage and achieving further progress. In another study, Sharifi (1999) designed a questionnaire, including 72 items, to evaluate the mentioned factors and determine the level of agility for manufacturing organizations. He assigned a score between 1 and 10 for each item. The questionnaire scored the mentioned factors based on the degree of volatility and their impact on the performance of the company. Yang et al. (2002) investigated the level of organizational agility using constituent elements of an organization. Ren (2000) proposed a model to assess the level of organizational agility using Analytical Hierarchy Process (AHP). In this model, paired comparison techniques have been used to assess agility. Lin et al (2006) considered fuzzy techniques appropriate to assess agility. Tesourlos and Valavanys (2002) investigated organizational agility based on fuzzy techniques and four dimensions, including structure, production, people, and information. Darezereshki and others (2009) conducted a study based on the indicators of agility and found out agility of governmental organizations in Yazd province is not optimal in terms of individual ability, human resources, information technology, innovation, educational programs, and culture of teamwork. Bagher Zadeh et al. (2009) demonstrated that the agility capabilities in the organization are not satisfactory and there is a gap between the current and the ideal status. Bagheri Karachi and Abbaspoor (2014) conducted a study to investigate the compliance of universities with the components of agile organization. They found out the mean scores of universities are not satisfactory in terms of the components of agile organization. Khorshid et al. (2010) determined the organizational agility in manufacturing companies using multi-criteria decision-making techniques and fuzzy approach. Due to the necessity of moving the university towards agility, this study 
aims to investigate the level of university organizational agility for branches of Islamic Azad University in Mazandaran Province from the perspective of faculty members.

\section{Research Methodology}

This study is a descriptive survey. The statistical population included the faculty members of the branches of Islamic Azad University in Mazandaran Province. The statistical sample included 270 people using stratified random sampling and Cochran's formula. Data were collected through a researcher-made questionnaire consisting of 70 questions on seven factors based on the 2-point Likert scale. The questionnaire simultaneously measures the ideal status and current situation. The validity of the questionnaire was examined based on the content validity and reliability of the questionnaire was determined as 0.78 using Cronbach's alpha. After using Kolmogorov-Smirnov test and ensuring the normal distribution of data, Independent Samples Test by SPSS software was used to analyze data. The findings were diagnosed to be generalized to the population.

Table 1: Factors and components related to organizational agility of the University

\begin{tabular}{|c|c|}
\hline Factor & component \\
\hline Organizational structure of university & $\begin{array}{l}\text { Monitoring and evaluation } \\
\text { Organizational strategy } \\
\text { Size of the organization } \\
\text { Low organizational complexity } \\
\text { Low organization recognition } \\
\text { centralization in the organization } \\
\text { Organizational communication } \\
\text { Partnerships and organizational integration } \\
\text { Scope of monitoring } \\
\text { Transparency in rules } \\
\text { team work } \\
\text { Environmental uncertainty }\end{array}$ \\
\hline $\begin{array}{l}\text { personal and professional characteristics of faculty } \\
\text { members }\end{array}$ & $\begin{array}{l}\text { Academic freedom and autonomy } \\
\text { Ethics and professional behaviors } \\
\text { Appropriate lesson plans } \\
\text { Professional specialization } \\
\text { effective research Projects } \\
\text { Scientific privacy }\end{array}$ \\
\hline \begin{tabular}{|l} 
Job characteristics of human resources \\
\end{tabular} & $\begin{array}{l}\text { Meet the needs of applicants } \\
\text { New responsibilities } \\
\text { The ability to provide new ideas } \\
\text { The ability and knowledge to negotiate } \\
\text { Organizational Empowerment } \\
\text { Participate in Self-Managed Teams } \\
\text { Increasing job involvement } \\
\text { Speed in skill development } \\
\text { Increasing digital literacy } \\
\text { Job enrichment } \\
\text { Multi-skilled employees } \\
\text { organizational appropriate communication }\end{array}$ \\
\hline organizational intelligence & $\begin{array}{l}\text { Knowledge of organizational missions } \\
\text { Recognition of the organization } \\
\text { The process of modernization and innovation } \\
\text { Applying organizational knowledge } \\
\text { The desire for change in the organization } \\
\text { Organizational Learning }\end{array}$ \\
\hline $\begin{array}{l}\text { Personal characteristics and management style and } \\
\text { organizational leadership }\end{array}$ & $\begin{array}{l}\text { Organizational Justice } \\
\text { Organizational assurance } \\
\text { Mental encouragement } \\
\text { Effective internal and external communication } \\
\text { Create an atmosphere and supportive environment for an agile system }\end{array}$ \\
\hline
\end{tabular}




\begin{tabular}{|l|l|}
\hline & $\begin{array}{l}\text { Reduction of political management at universities } \\
\text { Participation of faculty members, students and staff in the design and } \\
\text { implementation of programs of agility }\end{array}$ \\
\hline Organizational culture & $\begin{array}{l}\text { Culture of planning and foresight } \\
\text { culture of accountability } \\
\text { culture of variability and change entrepreneurship } \\
\text { Culture of accountability and social responsibility } \\
\text { culture of engaging in work } \\
\text { Network culture } \\
\text { Quality-oriented and excellence-oriented culture } \\
\text { Culture of innovation and entrepreneurship } \\
\text { Culture of learning and gaining knowledge (KM) }\end{array}$ \\
\hline Information Technology & $\begin{array}{l}\text { Technical and telecom infrastructure manpower infrastructure } \\
\text { Network security infrastructure } \\
\text { Electronic readiness infrastructure } \\
\text { Infrastructure of development for information technology applications }\end{array}$ \\
\hline
\end{tabular}

\section{Research Findings}

Table 2: Comparing the mean value of opinions of faculty members of Azad University about current and ideal status

\begin{tabular}{|l|c|c|c|c|c|}
\hline Component of agility assessment of university & $\begin{array}{c}\text { Mean value of } \\
\text { current status }\end{array}$ & $\begin{array}{c}\text { Mean value of } \\
\text { ideal status }\end{array}$ & $\begin{array}{c}\text { Difference between } \\
\text { current and ideal status }\end{array}$ & $\begin{array}{c}\mathrm{t}- \\
\text { value }\end{array}$ & Sig. \\
\hline Organizational structure of university & 45.3 & 58.4 & 13.1 & 5.43 & 0.0000 \\
\hline $\begin{array}{l}\text { personal and professional characteristics of } \\
\text { faculty members }\end{array}$ & 22.4 & 95.4 & 73.0 & 6.45 & 0.0000 \\
\hline Job characteristics of human resources & 93.3 & 59.4 & 02.1 & 3.65 & 0.0000 \\
\hline organizational intelligence & 20.3 & 18.4 & 98.0 & 3.55 & 0.0000 \\
\hline $\begin{array}{l}\text { Individual and professional characteristics of } \\
\text { management and organizational leadership }\end{array}$ & 89.3 & 25.4 & 36.0 & 7.43 & 0.0000 \\
\hline Organizational culture & 96.2 & 03.4 & 07.1 & 8.44 & 0.0000 \\
\hline Technology & 65.3 & 96.3 & 31.0 & 9.53 & 0.0000 \\
\hline
\end{tabular}

The findings of this study showed that there is a significant gap between current and ideal status in terms of achieving organizational agility.

\section{Discussion}

This study aims to investigate the level of university organizational agility for branches of Islamic Azad University in Mazandaran Province. The findings showed that the compliance with the factors related to the organizational agility is higher than the mean value from the perspective of the faculty members of the university and there is a significant difference between the current and ideal status. From the perspective of the faculty members, the greatest gap between current and ideal status is related to structural factors, human resources, and organizational culture. The research findings showed that three important elements of the organizational structure in the university, including low complexity, organizational formalization, centralization in the organization, are higher than the mean value. The organization which is designed based on agility has a unique structure and acts more efficiently. Some researchers such as Raschke (2010) have investigated organizational structure and its relationship with organizational agility. Raschke investigated significant relationship between organic and agile organizational structure. The research findings also suggested that the human resources in branches of Islamic Azad University in Mazandaran Province have deficiency. In agile organizations, the human resources are the main sources of productivity. It seems that increasing the level of organizational agility should be based on training the human resources in working groups. Thus, the employees will have significant and purposeful communication. Agile organizations try to reach a point that employees at all levels consider themselves and their colleagues responsible for the results of their work. Some researchers such as Plonka investigated the role of knowledgebased forces in creating agile organizations. In the present study, the organizational culture was not effective in creating agility. Nowadays, the role of organizational agility and its effectiveness in all areas, especially in universities, is an undeniable fact. Achieving agility can improve the quantity and quality of services, reduce costs caused by adverse 
reactions to changes, cause waste of resources, increase competitiveness, increase efficiency and productivity, and create motivation and job satisfaction in employees. According to the results of similar studies and the present study, good organizational culture can pave the way for the agility. Universities must create agile culture in the structure of the organization and between employees at the time of agility competition. In addition, they must institutionalize the culture of agility in the organizations by selecting the organizational culture in accordance with the organizational structure.

\section{References}

Arasteh, H. R. (2010). How do universities work? Tehran: Institute for Research and Planning in Higher Education.

Bagher Zadeh, M. R., Baloyee, E., Mafi, S. R. (2009). Evaluation of agility capabilities in governmental organization. Journal of Management, Vol. VII, Issue 18.

Baqerzadeh, M., Akbari Dibavar, A. (2010). investigating the relationship between organizational intelligence and organizational agility in cultural heritage tourism and handicrafts organization of East Azerbaijan Province. The first conference on organizational intelligence and business intelligence, Tehran, Islamic Azad University of Tehran, Department of Management, http://www.civilica.com/Paper-OIBI01-OIBI01_013.htm

Khorshid, S. (2010). A model for assessment and analysis of agile manufacturing organizations using multi-criteria decision-making techniques and fuzzy approach. Industrial Management Journal, Volume 2, Issue 4, pp. 37-56.

Dareh Zereshki, N., Roozbehani, S. (2009). Evaluating agility in service organizations, (Case Study: governmental organizations in Yazd Province). The Seventh International Conference on Management, Tehran, Research Group of Ariana, http://www.civilica.com/ Paper-IRIMC07

Mandana. F., Sohrabi, B., Raeisi. I. (2011). The Role of organizational structure in organizational agility. Research Journal of Human Resource Management, Volume 1, No. 3. pp. 135-143.

Booth CL, Hammer MP .(2008). Agility, the future ceramic manufacturing. In: A Collection of Papers Presented at the 96th Annual Meeting and the 1994 Fall Meetings of the Materials \& Equipment/White wares/Refractory Ceramics/Basic Science: Ceramic Engineering and Science

Breu, K., Hemingway, C.J., Strathern, M., Bridger, D. (2002). Workforce agility: the new employee strategy for the knowledge economiy. Journal of Information Technology 17(1), 21-31

Buchko.A.)2006). The Effect of leaders on value based management.www. Emerald in sight.com

Cakir, R., Ada, S. (2008). Can the organizational intelligence be developed in schools by in-service training?. world

Christopher.A.(2001), Diana M , Designing the Agile organization: Design principles and Practices.

Conboy K., Morgan L.; ( 2010) . Beyond the customer: Opening the agile systems development process; Information and Software Technology, 35 (5).

Deaton,K.(2006). Value Bossed Leadership Powerful and Intentional Available at www.Nacaorg

Ertürk, A. (2007). Increasing organizational citizenship behaviors of Turkish academicians: Mediating role of trust in supervisor on the relationship between organizational justice and citizenship behaviors. Journal of Managerial Psychology, 22(3), 257-277.

Fathian M, Fekri M .(2006), The Impact of Information Technology on Organizational Agility in Iranian Firms, International Journal of Agile systems and management

Fitzgerald C. A., Flood P. C., Regan P. O'. (2008). Ramamoorthy N.;"Governance structures and innovation in the Irish Software Industry"; Journal of High Technology Management Research, 19(1)

Hopp,W, J.,Van Oyen,M,P (2004) . Agile Workforce evaluation: a frame work for cross-training and Cordination. IIE Transaction 36 (10), $919-940$

Hoya, A. W., Wayne, K. H., \& Nan, M. K. (2008). Teacher's academic optimism: The development and test of a new construct. Teaching and Teacher Education, 24, 821-835. http://cou.on.ca/publications/reports/pdfs/the-universityprivate- sector-interface-and-the-on

Iravani, S.M.R., Krishnamurthy, V.(2007). Workforce agility in repaired and maintenance environments. Manufacturing and Service Operations Management 9(2),168-184

Johnson D. )2004). The university-private sector interface and the Ontario economy;. Available from: Lefter,V., Prejmerean, M., \& Vasilache, S. (2008).The dimension of organizational intelligence in Romanian companies-a human capital perspective. Academy of economic studies, Bucharest.

Lin, C., Chiu, H., and Chu, P.( 2006)."Agility Index in the Supply Chain, "International Journal of Production Economics(100:2), pp. 285299

Moore .P.R., Pu J., Ng H.C., Wong C.B., Chong S.K., Chen X. (2008). Adolfsson J., Olofsgard P., Lundgren J.-O.;"Virtual engineering: An integrated approach to agile manufacturing machinery design and integrated approach to agile manufacturing machinery design and control"; Mechatronics; 13(10), 2003.control"; Mechatronics; 13(10),

Organ, W. P., Podsakoff, M. P., and Mackenzie, B. S. (2006)."Organizational citizenship behavior is nature antecedents and consequences. A sage publication series

Plonka, F,S (1997). Developing a lean and agile work force. Human factors and Ergonomics in Manufacturing 7 (1), 11-20

Qumer A., Henderson-SellersB.;(2008). An evaluation of the degree of agility in six agile methods and its applicability for method engineering; Information and Software Technology, 50(4)

Ros I. Safinas M. Ramlee A. Malik,H. (2012). Relationship between Transformational Leadership and Employees' Job Satisfaction 
among the Academic Staff.

Ren.J.Yusuf.Y.Y.Burns.N.D.(2000).A prototype of Measurement System For Agile Enterprise in international Conference on Quality, Reliability and Maintenance. Oxford UK.PP.247-252.

Sharifi,H.(1999). Tools for assessing agility(needs and current level) in manufacturing organizations, Liverpool University, UK.

Raschke R. L.(2010);"Process-based view of agility: The value contribution of IT and the effects on process outcomes"; International Journal of Accounting Information Systems, (4).11

Sharifi, H, Zhang, Z. (1999). "A methodology for achieving agility in manufacturing organizations", international journal of production economics, 62, 7-22.

Sharpe, R. (2012) "Agile University: Building the Innovation and Improvement for a Better Student Experience" Higher Education SEMINAR. Thursday 15th. www.elementaleadership.co.uk.

Skarlicki, D. P., \& Latham, G. P. (1995). Organizational citizenship behavior and performance in a university setting. Revue Canadienne des Sciences de l'Administration,12(3), 175-182.

Sumukadas, N., Sawhney, R.)2004): Workforce agility through employee involvement. IIE Transaction 36(10), 1011-1021

Telford.R \& Masson.R (2005). The Congruence Of quality Values in higher education.WWW.Emerraldinsight.com- Tsourveloudis ,N.c,Valavanis ,K.P(2002). On the measurement of enterprise agility .journal of Intelligent and Robotic System 33.329-342.

Yang.S.I.Li.T.F.(2002).Agility Evaluation of mass Customization product manufacturing .Journal Of Materials Processing Technology 129.(3).640-644 